\title{
Description of the localized scleroderma subgroup of CARRAnet
}

\author{
Eveline $\mathrm{Wu}^{2^{*}}$, Egla C Rabinovich², Kathryn S Torok ${ }^{4}$, Suzanne C Li ${ }^{3}$, Robert C Fuhlbrigge ${ }^{1}$, CARRAnet Investigators $^{2}$ \\ From 2011 Pediatric Rheumatology Symposium sponsored by the American College of Rheumatology \\ Miami, FL, USA. 2-5 June 2011
}

\section{Purpose}

Localized scleroderma (LS) is a chronic inflammatory and fibrosing skin disease, more common in children. We present baseline data on the juvenile LS (jLS) cohort from the CARRAnet observational registry of pediatric rheumatologic disorders.

\section{Methods}

We performed a cross-sectional baseline analysis of registry data for jLS.

\section{Results}

Data were available on 44 children. $81.8 \%$ were female and $88.6 \%$ were Caucasian, of which $13.6 \%$ were Latino. Mean age at onset was 8.2 years $( \pm 4.0)$, yet first evaluation by a pediatric rheumatologist was 9.9 years $( \pm 4.2)$. Reported subtypes were: 34 linear scleroderma (LiScl: 25 trunk/limbs, 9 face/neck), 7 with circumscribed morphea (CM: 5 deep, 2 superficial), 6 with generalized morphea (GenM), 3 with eosinophilic fasciitis (EF), and 1 with pansclerotic morphea. There were 5 cases of mixed morphea (2 CM and LiScl, 1 with facial LiScl and GM, 2 with EF and linear lesions). Eight subjects had new lesions at time of enrollment. Features of active lesions included extension of existing lesions (13), warmth (13), erythematous/violacious color (13), and skin induration at lesion perimeter (10). Damage included subcutaneous atrophy (36), hyperpigmentation (35), dermal atrophy (31), hypopigmentation (19), hair loss (17), muscle atrophy (13), joint contracture (10), limb shortening (5), and hemifacial atrophy(1). Only three patients had extracutaneous manifestations, including two with arthritis. ANA positivity was found in $45 \%$ of tested patients, otherwise there were no consistent laboratory or imaging abnormalities. Table 1.

Mean physician global assessment was 1.61 (range 08 ) and mean CHAQ score was 0.19 (0-1.13). On a visual analog scale (0-10), mean parent/subject score of overall well-being was $1.80( \pm 1.66)$ and pain was $1.41( \pm 2.03)$. Health related quality of life was reported as excellent in 13 , very good in 22 , good in 7 , and poor in 2 subjects. A worst ever and current ACR functional class > I was reported in $33 \%$ and $20.5 \%$, respectively. Medications used are listed in table 2.

\section{Conclusion}

jLS is reported more frequently in females and Caucasians in the CARRA Registry. LiScl is the most common

Table 1

\begin{tabular}{lllllll}
\hline & $\begin{array}{l}\text { Antinuclear } \\
\text { antibody }\end{array}$ & $\begin{array}{l}\text { Elevated } \\
\text { lgG }\end{array}$ & Eosinophilia & $\begin{array}{l}\text { Abnormal } \\
\text { aldolase }\end{array}$ & $\begin{array}{l}\text { Abnormal creatine } \\
\text { kinase }\end{array}$ & $\begin{array}{l}\text { Abnormal CNS } \\
\text { imaging }\end{array}$ \\
\hline Positive & 14 & 6 & 5 & 3 & 1 & 1 \\
Negative & 17 & 20 & 30 & 16 & 24 & 10 \\
Unknown & 13 & 16 & 7 & 23 & 17 & 32 \\
Total & 44 & 42 & 42 & 42 & 42 & 36 \\
\hline
\end{tabular}

${ }^{2}$ Duke University Medical Center, Durham, NC, USA

Full list of author information is available at the end of the article 
Table 2

\begin{tabular}{llllll}
\hline & Oral methotrexate & Subcutaneous methotrexate & Mycophenolate mofetil & Intravenous corticosteroids & Longterm daily corticosteroids \\
\hline Subjects (\%) & $21 / 42(50 \%)$ & $15 / 42(36 \%)$ & $15 / 42(36 \%)$ & $28-36(78 \%)$ & $17 / 35(49 \%)$ \\
Current use & 12 & 4 & 4 & 5 & 5 \\
Past use & 9 & 11 & 11 & 23 & 12 \\
\hline
\end{tabular}

lesion subtype, representing $77 \%$ of all patients. $45 \%$ of the jLS cohort is ANA positive. Subcutaneous and oral MTX, MMF, and pulse CS are the most common medications used for treatment. There is an almost 2 year delay in referral to pediatric rheumatology. There is significant morbidity associated with jLS with $30 \%$ reporting limitation in functional capacity.

\section{Disclosure}

Eveline Wu: None; Egla C. Rabinovich: None; Kathryn S. Torok: None; Suzanne C. Li: None; Robert C. Fuhlbrigge: None; CARRAnet Investigators: None.

\section{Author details}

${ }^{1}$ Brigham and Women's Hospital, Boston, MA, USA. ${ }^{2}$ Duke University Medical Center, Durham, NC, USA. ${ }^{3}$ Hackensack University Medical Center, Short Hills, NJ, USA. ${ }^{4}$ University of Pittsburgh Medical Center, Pittsburgh, PA, USA.

Published: 13 July 2012

doi:10.1186/1546-0096-10-S1-A71

Cite this article as: Wu et al:: Description of the localized scleroderma subgroup of CARRAnet. Pediatric Rheumatology 2012 10(Suppl 1):A71.

Submit your next manuscript to BioMed Central and take full advantage of:

- Convenient online submission

- Thorough peer review

- No space constraints or color figure charges

- Immediate publication on acceptance

- Inclusion in PubMed, CAS, Scopus and Google Scholar

- Research which is freely available for redistribution

Submit your manuscript at www.biomedcentral.com/submit 